\title{
A Psicologia no Mundo Atual
}

\author{
Gislene Farias de Oliveira ${ }^{1}$
}

Resumo: Um mundo cheio de conceitos e definições, onde tudo tem que ter uma explicação. Este é o mundo atual, intelectualizado. Um mundo do saber, onde quem não possui um título ou uma titulação acadêmica corre o risco de ser "menos" ou "valer menos". A Psicologia, com toda sua subjetividade teria um lugar neste mundo? Qual sua definição e o seu papel social? Esta não parece uma questão tão fácil de responder. Não há "fórmulas psicológicas" que resolvam todos os problemas. Há indivíduos que se encontram para a tarefa de crescerem em comunhão.

Palavras-Chave: Psicologia, Atualidade, Subjetividade

\section{Psychology in the Present World}

\begin{abstract}
A world full of concepts and definitions, where everything must have an explanation. This is the current, intellectualized world. A world of know, where anyone who does not have a title or academic degree is in danger of being "less" or "worth less". Psychology, with all its subjectivity would have a place in this world? What is your definition and your social role? This does not seem as easy a question to answer. There is no "psychological formulas" to solve all problems. There are individuals who meet for the task to grow in communion.
\end{abstract}

Keywords: Psychology, Current Events, Subjectivity

De uma maneira geral, a maioria dos estudiosos concorda que, a Psicologia é uma ciência que estuda o comportamento humano. Seu principal objetivo é ajudar o homem a ter uma melhor compreensão de si, dos seus atos e pensamentos, de forma a lhes proporcionar um estado de coerência e bem estar consigo mesmo, com os seus relacionamentos e com o meio ambiente a sua volta.

A psicologia, em sua essência, está em nós, em cada decisão que tomamos, em cada temor, nos momentos em que nos sentimos fortalecidos e, nos momentos em que nos sentimos fracassados.

A palavra "Psicologia" deriva de dois termos gregos "psiqué" e "logos", e seu significado nos reporta a algo como "estudo da mente".

A psicologia, enquanto ciência, possui um objeto de estudo que é comportamento e todos os seus processos mentais envolvidos. Sua busca é por princípios gerais que os justifiquem. Há um foco maior nos seres humanos, mas também estuda comportamento dos animais, de forma a tornar possível algumas comparações.

O objetivo na compreensão dos comportamentos varia conforme o ramo da psicologia.

\footnotetext{
${ }^{1}$ Psicóloga, Doutora em Psicologia Social pela Universidade Federal da Paraíba - UFPB. E-mail: gislenefarias@gmail.com.
} 
http://idonline.emnuvens.com.br/id ISSN on-line: 1981-1179

Na psicologia clínica, há uma maior preocupação com o bem-estar e a satisfação com a vida; na psicologia escolar, há um maior interesse no sucesso acadêmico e no desempenho dos alunos. Já na psicologia organizacional o foco maior é na maximização do potencial humano e no reforço a características como liderança, capacidade criativa, ética como princípio guia de vida, e ênfase nos valores humanos que propiciem uma melhor convivência grupal. Portanto, embora haja um objetivo principal, que seria a compreensão do comportamento humano e os processos mentais que os explicam, existem outros objetivos associados a cada uma das áreas específicas da psicologia.

É importante referir que, qualquer das áreas não possui uma fronteira muito bem definida. Suas interfaces são difíceis de delimitar. Por isso que, o Psicólogo tem uma formação generalista, isto é, recebe um pouco de conhecimento de cada uma das áreas, com o qual, forma uma visão mais ampla e abrangente do mundo e dos problemas humanos nele presentes. Sendo o ser humano inevitavelmente um ser complexo, as soluções para suas dificuldades são igualmente complexas.

Um exemplo são as dificuldades de aprendizagem. Essas envolvem variáveis de dimensões diversas, desde a história da vida dos pais da criança, passando por suas experiências individuais passadas, seu contexto atual de moradia, condições econômicas e familiares, até as questões genéticas e culturais envolvidas, inclusive as questões deficitárias da formação dos seus professores.

É importante nesses casos, o desenvolvimento de uma visão para além do óbvio, podendo reconhecer as sutilezas e fatores mais essenciais enraizados num problema.

Em resumo, à semelhança de outras ciências, o resultado final dependerá de todo um processo de como foi conduzida a atuação profissional. Uma dificuldade pouco nos diz sobre a sua origem e possibilidade de mudança a curto, médio ou longo prazo.

Apesar de não ser uma ciência exata, trabalha com algumas técnicas capazes de mobilizar recursos pessoais dos envolvidos, possibilitando as chances de êxito em menor espaço de tempo. Para cada caso, há um procedimento particular, de acordo com a demanda do cliente.

Como qualquer ciência humana, a Psicologia é uma ciência com subjetividades e sem exatidões. Apesar disso, pode fazer uma enorme diferença na vida das pessoas, na sua forma de ver o mundo, podendo implicar em uma vida mais ajustada, onde o indivíduo possa se sentir inteiro. Uno com o universo e, por que não dizer, mais feliz.

\section{Como citar este artigo (Formato ISO):}

OLIVEIRA, Gislene Farias.. A Psicologia no mundo atual. Id on Line Revista de Psicologia, Fevereiro de 2014, vol.8, n.22, p. 08-09. ISSN 1981-1189.

Id en lime Revista de Psicologia. Ano 8, No. 22, Fevereiro/2014 - ISSN 1981-1179. Edição eletrônica em http://idonline.emnuvens.com.br/id 